\title{
INTEGRASI ISLAM DAN SAINS: SEBUAH TELAAH EPISTEMOLOGI
}

\author{
Moch. Nurcholis \\ IAI Bani Fattah Jombang \\ moch.nurcholis@iaibafa.ac.id
}

\begin{abstract}
Abstrak
Pemisahan Islam dan sains berakibat pada kemunduran peradaban umat Islam, di satu sisi, dan krisis eksistensial pada sisi yang lain. Integrasi keduanya dapat mengantarkan umat Islam pada prestasi peradaban sekaligus kesempurnaan moral. Upaya Integrasi Islam dan sains telah dimulai oleh para pemikir Muslim baik melalui dewesternisasi ilmu, Islamisasi ilmu, ilmuisasi Islam, dan lain sebagainya.

Berbeda dengan tulisan serius para cendekiawan muslim tersebut, tulisan ini hanya akan berupaya mendeskripsikan integrasi bangunan epistemologis Islam dengan sains melalui library research berdasar pada data kepustakaan yang terkait. Fokus tulisan ini dibatasi pada masalah sebab keterpisahan umat Islam dengan sains dan bagaimana pola keselarasan espistemologi Islam dan sains.

Tulisan ini menyimpulkan dua hal. Pertama, keterpisahan Islam dengan sains lebih dikarenakan aspek historis, sosiologis, politis dan bukan karena faktor sistem ajaran. Islam sebagai sebuah ajaran yang komprehensif tidak menempatkan "ilmu agama" dan "ilmu umum" dalam posisisi diametralparadoksial. Kedua, pola keselarasan epistemologi Islam dan sains adalah kulli-juz'i (universal-partikular). Dengan kata lain, sains merupakan salah satu bagian dari ajaran Islam dalam satu keutuhan dan kesatuan sistem yang disebut sebagai way of life (jalan hidup).
\end{abstract}

\section{Kata Kunci: Islam, Sains, Epistemologi}

\begin{abstract}
The separation of Islam and science resulted in the decline of Muslim civilization, on the one hand, and an existential crisis on the other. The integration of fatigue can lead Muslims to achievement as well as moral perfection. Efforts to integrate Islam and science have been initiated by Muslim thinkers through the dewesternization of science, the Islamization of science, the science of Islam, and others.

In contrast to the serious writings of these Muslim scholars, this paper will only attempt to describe the integration of Islamic epistemological buildings with science through library research based on related library data. The focus of this paper is on the problem of the separation of Muslims from science and how the pattern of harmony between Islamic espistemology and science.

This paper concludes two things. First, the separation of Islam and science is based more on historical, sociological, political aspects and not because of the teaching system factor. Islam as a teaching includes not placing "religious knowledge" and "general science" in a diametral-paradoxical position. Second, the pattern of harmony between Islamic and scientific
\end{abstract}




\section{Moch. Nurcholis}

epistemology is kulli-juz'i (universal-particular). In other words, science is a part of Islamic teachings in a whole and unified system known as a way of life.

\section{Keywords: Islam, Science, Epistemology}

\section{A. Pendahuluan}

Pelepasan sain dari agama mengakibatkan krisis epistemologis dalam mendapatkan ilmu pengetahuan. Sains, yang hanya membatasi diri pada objek empirik dengan mengandalkan indera sebagai alat pengetahuan dan rasionalitas sebagai alat ukur kebanaran, telah secara sadar menghilangkan kesempatan mendapatkan pengetahuan dari sumber pengetahuan lain yang mampu menjangkau wilayah metafisika, suprarasional serta terlepasnya etika dari dirinya. Hilangnya etika yang merupakan bagian dari ajaran agama (dan tentunya juga merupakan bagian dari filsafat sebagai sokoguru sains) dari diri sains lebih jauh berakibat pada krisis eksistensial manusia modern tentang hakekat dan makna kehidupan yang berdampak pada krisis spiritual, hilangnya makna, visi, dan legitimasi kehidupan, serta rasa terasing dari diri manusia itu sendiri. ${ }^{1}$

Krisis eksistensial bermula saat manusia (saintis) modern mengingkari keberadaan Tuhan dan mengharap janji kebahagiaan yang ditawarkan oleh saintisme pasca era renaisans (abad pencerahan) di dunia Barat. Saintis berpandangan bahwa alam yang wujud ini berjalan secara evolutif dengan pola saling mencipta dengan sendirinya dan tidak bergantung pada hal di luarnya. Alam semesta dianggap sebagai sesuatu yang kekal wujudnya dan berkembang sesuai dengan hukumnya sendiri dan tidak bergantung pada tuhan sebagai pencipta. Kebahagiaan dalam pandangan saintis dimaknai sebagai bersumber dari dunia materi (dunia yang terindera) belaka yang perkembanganya selalu beriringan dengan perkambangan dan kemajuan sains yang dicapai oleh uman manusia. $^{2}$

Pada sisi lain, pelepasan agama (masyarakat Islam) terhadap sains mengakibatkan kemunduran prestasi peradaban masyarakat muslim, sikap menutup diri, dan keterbelakangannya pada pergaulan dunia modern. Umat Islam

\footnotetext{
${ }^{1}$ Haidar Bagir, Epistemologi Tasawuf (Bandung: Mizan, 2018), 55.

${ }^{2}$ Sayed Muhammad Naquib al-Attas, Islam Dan Filsafat Sains (Bandung: Mizan, 1989), 27.
} 
harus kembali memiliki sifat terbuka dalam menerima sains dari mana dan dari siapa ia bersumber. Sains harus disadari sebagai sebuah warisan peradaban umat manusia dalam proses saling menerima dan memberi dalam bentangan perjalanan sejarah umat manusia itu sendiri. Sikap menutup diri terhadap perkembangan sains, hanya karena saat ini sedang dimiliki oleh dunia barat, merupakan sikap tidak realistis dan ahistoris. ${ }^{3}$ Sikap terbuka terhadap ilmu pengetahuan merupakan modal penting yang telah dicontontohkan oleh para pemikir muslim era keemasan Islam saat berinteraksi dengan filsafat Yunani, yang meski diliputi unsur spekulatif, telah dapat mendorong mereka untuk mengungkap pengetahuan alam empiris sebagaimana disebut dalam al-Qur'an. ${ }^{4}$

Integrasi Islam dengan sains bagi umat Islam dengan demikian, sangat diperlukan oleh kedua belah pihak. Islam memerlukan sains untuk memperkokoh dogma ajarannya sedangkan sainstis memerlukan Islam sebagai pembimbing orientasi kearah yang seharusnya. Melengkapi pernyataan Emanual Kant, sebagaimana dicuplik Suparman Syukur, yang mengatakan bahwa indera dapat menyerap sesuatu, akal dapat memikirkan sesuatu, sehingga menghasilkan ilmu pengetahuan, maka agama dapat membimbing ilmu pengetahuan ke arah yang benar, yakni untuk kebaikan manusia dan keseimbangan kosmos. ${ }^{5}$

Upaya untuk mengintegrasikan Islam dan sains banyak dilakukan oleh sarjana Islam kontemporer, baik melalui pola dewesternisasi ilmu oleh M. Naquib al-Attas, Islamisasi ilmunya Raji al-Faruqi, Ziauddin Saddar dengan Islam peradabannya, Mehdi Golshani dengan ide sains Islam ataupun ilmuisasi Islam seperti yang digagas oleh Kuntowijoyo melalui integralisasi dan objektifikasi. Selain itu, upaya integrasi juga mulai banyak dilakukan oleh para cendekiawan muslim di beberapa perguruan tinggi, seperti Amin Abdullah (teori jaring labalabanya) dan Imam Suprayogo (dengan pohon ilmunya). Dalam tataran lebih konkrit, integrasi Islam dan sains berwujud dalam bentuk metode studi Islam

\footnotetext{
${ }^{3}$ Kuntowijoyo, Islam Sebagai Ilmu: Epistemologi, Metodologi, Dan Etika (Yogyakarta: Tiara Wacana, 2007), 89.

${ }^{4}$ Haidar Bagir, Mengenal Filsafat Islam: Pengantar Filsafat Yang Ringkas, Menyeluruh, Praktis, Dan Transformatif (Bandung: Mizan, 2020), 51.

5 Suparman Syukur, Epistemologi Islam Skolastik: Pengaruhnya Pada Pemikiran Islam Modern (Yogyakarta: Pustaka Pelajar, 2007), 49.
} 


\section{Moch. Nurcholis}

melalui pendekatan multidispliner, interdisipliner, dan transdisipliner sebagaimana digagas oleh Mujamil Qomar dan Amin Abdullah.

Berbeda dengan tulisan serius para cendekiawan muslim tersebut, tulisan ini hanya akan berupaya mendeskripsikan integrasi bangunan epistemologis sains dengan keilmuan Islam melalui metode library research berdasar pada data kepustakaan yang terkait. Fokus tulisan ini dibatasi pada masalah sebab keterpisahan umat Islam dengan sains dan keselarasan espistemologi Islam dan sains.

\section{B. Pembahasan}

1. Epistemologi Sebagai Basis Integrasi

Salah satu objek pengetahuan yang menyibukkan filsafat sampai hari ini adalah gejala pengetahuan atau lebih tepatnya gejala keilmuan. ${ }^{6}$ Kata pengetahuan dan keilmuan jika ditelisik lebih jauh terdapat perbedaan yang cukup signifikan. Ilmu semakna dengan ilm (bahasa Arab) dan science (bahasa Inggris). Sedangkan pengetahuan semakna dengan kata knowledge (bahasa Inggris) dan ma'rifah (bahasa Arab).

Pengetahuan diartikan sebagai hasil pikir manusia yang dengannya manusia akan menemukan sekalgus menghayati kehidupannya secara sempurna. Sedangkan ilmu tidak lain adalah kumpulan pengetahuan dengan kriteria tertentu yang membedakannya dengan pengetahuan yang lain. ${ }^{7}$ Dalam bahasa yang lebih sederhana, ilmu merupakan salah satu bagian pengetahuan dengan ciri, tahapan, dan metode tertentu sehingga ia dapat tersusun secara sistematis dan dengan sadar menuntut kebenaran. ${ }^{8}$

Dalam kajian filsafat, cabang kajian tentang pertanyaan-pertanyaan yang bersifat menyeluruh dan mendasar tentang pengetahuan disebut dengan espistemologi. ${ }^{9}$ Epistemologi merupakan teori filsafat yang berusaha membahas secara mendalam tentang gejala atau fenomena yang tertangkap (baik oleh nalar

\footnotetext{
${ }^{6}$ J. Sudarminta, Epistemologi Dasar (Yogyakarta: Kanisius, 2002), 18.

${ }^{7}$ Jujun S. Suriasumantri, Ilmu Pengetahuan (Jakarta: Yayasan Obor Indonesia, 2009).

${ }^{8}$ Juhaya S. Praja, Aliran-Aliran Filsafat Dan Etika (Jakarta: Prenada Media, 2003).

${ }^{9}$ J. Sudarminta, Epistemologi Dasar, 12.
} 
maupun indera) dalam usaha untuk mendapatkan pengetahuan yang tersimpan di dalamnya. $^{10}$

Epistemologi atau dapat disebut juga sebagai filsafat pengetahuan, ${ }^{11}$ terdiri dari kosa kata dalam bahasa Yunani "episteme" yang memiliki makna pengetahuan dan kosa kata logos yang berarti ilmu, perkataan, pikiran. Dalam bahasa Yunani, akar kata episteme adalah kata epistamai yang berarti menempatkan atau mendudukkan atau meletakkan. Sehingga secara harfiah kata episteme bermakna sebuah pengetahuan tentang bagaimana seorang ilmuwan mendudukkan sesuatu sesuai dengan kedudukan yang seharusnya. ${ }^{12}$ Jika dimaknai bersamaan dengan kata logos, epistemologi berarti ilmu tentang pengetahuan dalam menempatkan suatu hal secara proporsional dan apa adanya.

Pada mulanya, para filosof pra-Sokratik tidak terlalu mengindahkan cabang dari kajian filsafat ini, sebab mereka lebih berkonsentrasi terhadap hal-hal yang bersifat kodrati dan kemungkinan perubahan dari segala apa yang tampak secara indrawi. ${ }^{13}$ Baru kemudian, setelah muncul era Plato, istilah epistomologi ini muncul, dan bahkan ia disebut sebagai peletak dasar epistemologi, sebab Platolah orang yang dikenal pertama kali memprakarsai kajian yang berkisar pada pertanyaan: "Apakah itu pengetahuan? Dimanakah umumnya pengetahuan ditemukan? Sejauh manakah apa yang kita anggap sebagai pengetahuan benarbenar merupakan pengetahuan?"14 Dari masalah-masalah dasar yang dikaji oleh Plato ini diketahui bahwa salah satu tujuan epistemologi adalah untuk mengkaji dan mencoba menemukan sumber-sumber, dasar, dan validasi (keabsahan) kebenaran sebuah ilmu pengetahuan.

Jika Plato dianggap sebagai penemu espistomologi, tokoh yang dianggap memperkenalkan istilah epistemologi dan membedakannya dengan dengan cabang ontologi, adalah J.F. Ferrier. Berbeda dengan logika yang menkaji persoalan sains formal berkenaan prinsip-prinsip penalaran, menurut J.F. Ferrier, epistemologi memiliki kajian pokok berupa asal, struktur, metode, dan validitas ilmu pengetahuan (the branch of philosophy wich investigates the origin, structure,

\footnotetext{
${ }^{10}$ Abu Yasid, Logika Ushul Fikih (Yogyakarta: IRCiSoD, 2019), 29.

${ }^{11}$ Kenneth T. Gallagher, Epistemologi (Yogyakarta: Kanisius, 1994).

12 J. Sudarminta, Epistemologi Dasar.

${ }^{13}$ Kenneth T. Gallagher, Epistemologi.

14 Ibid.
} 


\section{Moch. Nurcholis}

methods, and validity of knowledge $).^{15}$ Dengan kata lain, epismologi sebagai sebuah pendekatan berupaya untuk mengungkap sumber, metode, dan validitas sebuah ilmu pengetahuan.

Epistemologi sebagai basis integrasi keilmuan Islam dan sains difungsikan untuk menemukan titik temu paradigma, objek, metode, dan kriteria yang digunakan untuk mendapatkan ilmu pengetahuan oleh keduanya. Usaha integrasi ini penting dilakukan di tengah sikap dikotomis umat Islam terhadap ilmu pengetahuan yang mengarah pada penolakan keabsahan dari masing-masing pihak dan berakibat pada kemunduran peradaban umat Islam sendiri. ${ }^{16}$ Hal mana tidak terjadi pada era awal ilmuwan Islam ketika seluruh keilmuan, "ilmu agama" dan "ilmu umum", diinsafi sebagai yang terintegrasi dan wajib dipelajari sebagai bentuk pelaksanaan perintah "iqra" dengan media pengetahuan berupa ayat qawliyah (al-Qur'an) dan ayat kawniyah (alam semesta) yang sama-sama bersumber dari realitas sejati, Allah SWT. ${ }^{17}$

Islam sebagai agama dan sains, sebagaimana diungkap Mujamil Qomar, memiliki peran yang sama-sama penting dan saling mengisi dalam pemenuhan hajat kehidupan umat manusia. Keterpaduan diantara keduanya mengantarkan umat manusia pada ketercapain prestasi dan kemajuan peradaban, di satu sisi, dan pada saat bersamaan tetap berpegang teguh pada moral dan etik yang berlandaskan pada aspek kemanusian dan keseimbangan kosmos. ${ }^{18}$

\section{Keterpisahan Dunia Islam dengan Sains}

Membincang kaitan dunia Islam pasca era kejayaannya $(1350 \mathrm{M})$ dengan sains pasca revolusi ilmiahnya di dunia Barat (1543-1600 M.) merupakan upaya mengkaitkan dua hal yang dianggap memiliki hubungan diametral dan paradoksial. Integrasi diantara keduanya mengasumsikan adanya perbedaan jalan

\footnotetext{
${ }^{15}$ Idri, Epistemologi Ilmu Pengetahuan, Ilmu Hadis, Dan Ilmu Hukum Islam (Jakarta: Prenadamedia Group, 2015), 3.

${ }^{16}$ Mulyadhi Kartanegara, Integrasi Ilmu: Sebuah Rekonstruksi Holistik (Bandung: Arasy Mizan, 2005), 44.

${ }^{17}$ Ahmad Tafsir, Filsafat Pendidikan Islami: Integrasi Jasmani, Rohani, Dan Kalbu Memanusiakan Manusia (Bandung: Remaja Rosdakarya, 2017), 103.

${ }_{18}$ Mujamil Qomar, Pendidikan Islam Multidispliner, Interdisipliner, Dan Transdisipliner (Malang: Madani Media, 2020), 36.
} 
yang ditempuh oleh keduanya dalam menemukan ilmu pengetahuan, antara dogma ${ }^{19}$ dan paradigma. ${ }^{20}$ Munculnya pandangan yang meletakkan Islam seolah bertentangan dengan sains dikarenakan faktor kesejarahan ketika umat Islam tidak mampu lagi menjaga sains sebagai pusaka bersama seluruh umat manusia yang membentang dari Yunani, China, Islam, hingga Eropa. ${ }^{21}$ Sebaliknya, Islam sebagai sebuah ajaran sama sekali tidak bertentangan dengan sains karena ajarannya tidak hanya berisi ajaran tentang ritualistik semata tetapi juga menyentuh seluruh aspek kehidupan, baik yang berdimensi dunyawi maupun berdimensi $u k h r a w i{ }^{22}$ Lebih dari itu, dalam sistem kepercayaan, Islam memiliki tokoh sentral yang dikenal sebagai Bapak ilmu pengetahuan dan pemikiran bernama Nabi Idris yang disebut dengan nama Hermes Trimegistus (Hermes pemilik tiga kebesaran) seorang penguasa, filosof, dan ilmu pengetahuan. ${ }^{23}$

Dalam catatan sejarah, sebagaimana dinyatakan oleh Abdus Salam, awal keterpisahan umat Islam dengan sains dimulai pada kisaran tahun 1217 ketika seorang non-muslim berkewarganegaraan Skotlandia bernama Michael datang ke universitas Islam di Spanyol tepatnya kota Toledo dan Kordoba dengan misi untuk menyalin karya-karya Aristoteles yang masih berbahasa Arab ke dalam bahasa latin. Setelah berhasil menyalin karya filosof Yunani itu, pada kisaran tahun 1231 ia pergi ke Italia dan bertemu dengan salah satu ahli bedah Henrik Harpestraeng di Salerno. Keduanya kemudian bekerjasama menyusun satu risalah sebanyak tujuh jilid tentang bedah dengan menggunakan karya al-Razi dan Ibnu Sina sebagai referensi utamanya. Sebuah risalah yang menandai lahirnya kajian sains di dunia Barat. ${ }^{24}$ Maraknya kajian sains di dunia Barat dilukiskan dengan

\footnotetext{
${ }^{19}$ Dogma adalah satu hal yang kebenarannya diyakini dengan sendirinya dan menjadi dasar pembenar untuk hal-hal yang lain. Sedangkan paradigma adalah paradogma, landasan yang menjadi dasar pembenaran terhadap dogma. Dalam pengertian ini, pengetahuan yang didasarkan pada dogma berangkat dari sebuah keyakinan, sedangkan kebenaran yang berangkat dari paradigma dapat disebut berangkat dari keraguan.Zainal Habib, Islamisasi Sains:Mengembangkan Integrasi, Mendialogkan Perspektif (Malang: UIN-MALANG PRESS, 2007), 19.

${ }^{20}$ Haidar Bagir dan Ulil Abshar Abdalla, Sains Religius, Agama Saintifik: Dua Jalan Mencari Kebenaran (Bandung: PT. Mizan Pustaka, 2020), 25.

${ }^{21}$ Abdus Salam, Sains Dan Dunia Islam Menghidupkan Kembali Sains Di Negara-Negara Arab Dan Islam, Terj. Achmad Baiquni (Bandung: Pustaka, 1982), 9.

${ }^{22}$ Ismai'il Raji Al-Faruqi, Islamisasi Pengetahuan, Terj. Anas Mahyuddin (Bandung: Pustaka, 1984), 10.

${ }^{23}$ Haidar Bagir, Epistemologi Tasawuf, 36.

${ }^{24}$ Salam, Sains Dan Dunia Islam Menghidupkan Kembali Sains Di Negara-Negara Arab Dan Islam, Terj. Achmad Baiquni, 9.
} 


\section{Moch. Nurcholis}

sangat baik oleh sosiolog Muslim terkenal, Ibnu Khladun, dalam karyanya Mukaddimah:

"Balaghana> li ha>dha al-'ahd anna ha>dhih al-'ulu>m al-falsafiyyah bi bila>d al-ifranjah min ard\} ru>mah wa ma> ilayha>min al-'udwah alshama>liyyah na>fiqat al-aswa>q. Wa anna rusu>maha> huna>ka mutajaddidah wa maja>lis ta'li>miha> muta'addidah wada>wi>naha> ja>mi'ah wahjamalataha> mutawaffiru>n wa t\}alabataha> mutakaththiru>n. Wa Allah A'lam bi ma> huna>lika wa huwa yakhluq ma> yasha> 'wa yakhta>r. ${ }^{, 25}$

"Telah sampai (berita) pada kita pada era ini, bahwa ilmu filsafat di negaranegara Perancis (Eropa), dari tanah Roma dan bagian lain dari lembah sebelah utara telah kehilangan peminatnya. Dan sesungguhnya skema (deskripsi) tentang ilmu filsafat telah dimodernkan, forum kajiannya beraneka ragam, catatannya (referensinya) komprehensif, pembawanya tersedia, dan banyak para pelajarnya. Allah Maha Mengetahui tentang apa yang ada di sana. Dia mencipta sesuatu yang Ia kehendaki dan yang Ia pilih."

Tumbuh suburnya minat untuk mengkaji sains di dunia Barat berbanding terbalik dengan sikap dikotomis masyarakat Muslim yang menempatkan sains bukan sebagai bagian ajaran agama yang harus diprioritaskan. Relasi masyarakat Muslim dengan dunia Barat dalam bidang sains dapat ditamsilkan layaknya dua piringan timbangan yang ketika salah satu sisinya menguat maka sisi yang lain mengalami pelemahan. Sikap dikotomis dan cenderung apatis terhadap persoalan sains ditambah dengan kemunduran politik umat Islam serta pandangan yang menempatkan sains sebagai produk pemikiran di luar Islam, pada akhirnya telah berjasa besar mengantarkan umat Islam untuk benar-benar berpisah dengan kajian sains. $^{26}$

Faktor penting yang turut menyumbang keterpisahan dunia Islam dengan sains adalah fakta bahwa umat Islam tidak lagi mencurahkan perhatiannya -untuk tidak mengatakan menolak- terhadap kajian filsafat yang secara nyata telah terbukti pada kisaran abad ke 15 mengantarkan dunia Islam sebagai yang terdepan dalam bidang sains dan bahkan dianggap capaian prestasi sainsnya lebih maju jika dibanding prestasi sains pada abad-abad setelahnya. Umat Islam agaknya lupa

\footnotetext{
${ }^{25}$ Abdurrahman Ibn Khaldun, Muqaddimah (Damaskus: Dar Ya'rab, 2004).

${ }^{26}$ Abdalla, Sains Religius, Agama Saintifik: Dua Jalan Mencari Kebenaran, 77.
} 
bahwa para saintis Islam yang termuka, selain ahli sebagai ilmuwan agama, juga merupakan seorang filosof. ${ }^{27}$

Selain faktor internal, keterpisahan umat Islam dengan sains juga dipengaruhi oleh pandangan filosof dan saintis Barat yang mengalami traumatik dengan kelompok gereja yang memiliki hubungan dengan penguasa telah bersama-sama menekan para pemikir kemanusiaan. Pemberontakan terhadap superioritas gereja ditambah dengan keberhasilan dunia Barat mengembangkan sains berakibat pada kesombongan kelompok ini untuk serta merta menolak kebenaran di luar sains, termasuk kebenaran yang berasal dari agama. Agama, termasuk di dalamnya Islam, dengan demikian dianggap sebagai penghalang kemajuan sains dan sama sekali tidak memberi sumbangsih pemikiran terhadap perkembangan sains. ${ }^{28}$

Perkembangan sains dalam pandangan saintis Barat beriringan dengan tingkat pemahaman dan penemuan ilmu pengetahuan oleh alam pikiran manusia sendiri berdasar pada pengalaman inderawi. Tuhan bagai mereka dianggap sebagai yang tidak memiliki esensi (non-esensial). Kepercayaan terhadap wujudnya tuhan hanya akan berakibat menghambat akal pikiran manusia dalam mengembangkan ilmu pengetahuan. Meski mereka percaya bahwa alam semesta memiliki hukum yang tetap dan teratur (law of nature), namun hukum alam berjalan secara natural dan secara mandiri tanpa ada unsur pengerak di luarnya. Dalam konteks inilah, muncul pernyataan-pernyataan yang bernada "sangat rasional" dari kelompok saintis Barat sekuler berdasarkan metode yang disebutnya sebagai metode ilmiah, seperti statemen Nietzsche: "God is dead", atau pernyataan Hegel: "Saya bisa menciptakan manusia apabila ada air, zat kimia, waku, dan kesempatan", dan juga pernyataan Imanuel Kant: "Berikan saya satu benda, akan saya ajarkan kepadamu bagaimana alam semesta tercipta darinya". ${ }^{29}$ Pernyataan filosof-saintis barat yang bernada "sekuler" semacam ini pada akhirnya turut menyumbangkan kristalisasi pandangan dikotomis antara penganut sains Barat di satu sisi, dan para agamawan di sisi yang lain.

\footnotetext{
${ }^{27}$ Haidar Bagir, Mengenal Filsafat Islam: Pengantar Filsafat Yang Ringkas, Menyeluruh, Praktis, Dan Transformatif.

${ }_{28}^{28}$ Abdalla, Sains Religius, Agama Saintifik: Dua Jalan Mencari Kebenaran, 26.

${ }^{29}$ Habib, Islamisasi Sains:Mengembangkan Integrasi, Mendialogkan Perspektif, 19.
} 
3. Titik Persinggungan Epistemologi Islam dan Sains

Rene Descartes disebut sebagai orang yang pertama-tama mengembangkan pemikiran modern di dunia Barat. Pandangannya tentang realitas kebenaran dan hakekat pengetahuan menempatkan manusia sebagai subjek pengetahuan yang sama sekali terpisah atau memiliki jarak dengan objek pengetahuan (realitas di luar manusia sendiri). Manusia sebagai subjek pengetahuan dengan sendirinya mampu bersikap aktif dan sekaligus objektif dalam menangkap realitas di luarnya sebagai sebuah ilmu pengetahuan. Pemikiran Descartes tentang metode memperoleh pengetahuan ini dalam dunia modern diyakini sebagai sebuah cara yang paling sahih dalam menemukan hakekat kebenaran atau yang disebut sebagai scientific method (metode ilmiah). ${ }^{30}$

Metode ilmiah yang digagas oleh Descartes, dalam perkembangannya memadukan dua corak sekaligus dalam menemukan sebuah kebenaran, yakni rasional-deduksi atau rasionalisme dan empiris-induksi atau yang dikenal empirisme. Pola kerja rasionalisme dalam menemukan kebenaran dimulai dengan menyusun premis-premis dalam bentuk proposisi (pernyataan) yang kemudian ditarik simpulannya. Sedangkan dalam corak empirisme, penarikan simpulan sebagai sebuah kebenaran didasarkan pada fakta-fakta empirik. ${ }^{31}$ Pengetahuan dalam kacamata sains, dengan demikian, dimaknai sebagai pengetahuan yang hanya mengkaji objek empirik berdasarkan paradigma sains (logico-hypotheticoverificativ) dan dengan menggunakan metode ilmiah. Kebenaran dalam pengetahuan sains mensyaratkan adanya unsur rasional dan empiris sekaligus. ${ }^{32}$ Pengetahuan ilmiah, sebagaimana dinyatakan Zainal Habib, berangsur telah melahirkan mazhab scientisme yang menilai kebenaran segala sesuatu, termasuk ajaran agama, hanya apabila dapat dibuktikan secara nalar dan riil. ${ }^{33}$

Kepongahan kelompok saintis dalam monopoli sebuah kebenaran tergambar dalam teori August Comte melalui "hukum tiga tahap perkembangan". Dalam

\footnotetext{
${ }^{30}$ Abdalla, Sains Religius, Agama Saintifik: Dua Jalan Mencari Kebenaran, 24.

${ }^{31}$ Haidar Bagir, Epistemologi Tasawuf, 36.

32 Ahmad Tafsir, Filsafat Pendidikan Islami: Integrasi Jasmani, Rohani, Dan Kalbu Memanusiakan Manusia, 105.

${ }^{33}$ Habib, Islamisasi Sains:Mengembangkan Integrasi, Mendialogkan Perspektif, 34.
} 
teorinya, Comte, sebagaimana dicuplik Saepuddin, menyatakan bahwa setiap kehidupan manusia berkembang melalui tiga tahap yang berjalan secara gradual, yakti teologis, metafisik, dan positif. Dalam tahap teologis yang bersifat fiktif manusia membutuhkan peran agama untuk mengatasi problematika hidupnya. Peran agama pada tahap metafisik, kemudian tergeser oleh filsafat. Pada tahap positif, peran filsafat pada akhirnya harus tergantikan oleh peran sains. Tahap sains dianggap sebagai tahap yang telah mengantarkan manusia pada puncak peradaban dan kedewasaan sebab dalam sains terkandung kepastian, ketetapatan, konkret, dan bernilai manfaat. ${ }^{34}$

Teori Comte tentang tahapan perkembangan manusia yang menempatkan agama sebagai yang paling awal dan perannya telah tergeser oleh filsafat dan sains tampaknya tidak dapat diberlakukan untuk agama Islam. Sebab dalam kesejarahannya, kajian tentang filsafat dan sains berjalan secara bersamaan dan dianggap sebagai bagian dari menjalankan agama. Filsafat, misalnya, oleh para pemikir muslim tidak hanya dibangunkan sebuah argumentasi tentang kebolehannya akan tetapi tentang keutamaan mempelajarinya sebagai sebuah saranan untuk mengetahu segala yang wujud. Al-Kindi, sebagai filosof muslim tertua telah menulis dua karya besar berjudul "fi falsafah al-'ulya" dan "kasyf almanahij al-adillah" yang berisi tentang pembelaan tentang filsafaat yang bersendikan ketuhanan. Selain sebagai seorang filosof, al-Kindi juga dikenal sebagai ahli dalam bidang kedokteran, geografi dan fisika. ${ }^{35}$

Selain al-Kindi, dunia Islam telah banyak menyumbangakan ulama-intelek, meminjam istilah Mujamil Qomar, ${ }^{36}$ yang sangat berpengaruh dalam bidang sains,

\footnotetext{
34 AM. Saepuddin, Desekularisasi Pemikiran, Landasan Islamisasi Sains (Bandung: Mizan, 1996), 6. Periodesasi sejarah semacam yang dikenalkan oleh Comte, dalam konteks politik umat Islam di Indonesia juga pernah disinggung oleh Kuntowijoyo. Dalam pandangannya, Kuntowijoyo, membagi periode sejarah politik umat Islam Indonesia menjadi tiga tahap. Pertama, tahap mitos dengan menggunakan cara berpikir pralogis dalam bentuk magi. Kedua, tahap idiologi dengan metode berpikir non-logis dalam bentuk abstrak atau apriori. Ketiga, tahap ilmu dengan menggunakan cara berpikir logis dan dalam bentuk empiris atau konkret. Selengkapnya dalam Kuntowijoyo, Islam Sebagai Ilmu: Epistemologi, Metodologi, Dan Etika, 77.

${ }^{35}$ Haidar Bagir, Mengenal Filsafat Islam: Pengantar Filsafat Yang Ringkas, Menyeluruh, Praktis, Dan Transformatif.

${ }^{36}$ Integrasi antara ilmu agama dan ilmu umum di tengah dikotomi ilmu pengetahuan di dunia Islam mensyaratkan adanya saling kepedulian diantara umat Islam sendiri untuk memperkokoh penemuan kebenaran ilmiah dari sebuah dogma agama. Para agamawan hendaknya melengkapi keilmuannya dengan wawasan sains sehingga memiliki kapasitas sebagai ulama-intelek. Sebaliknya, para saintis muslim juga harus mendalami khazanah ilmu agama sehingga mengantarkan dirinya pada tingkatan intelek-ulama.
} 


\section{Moch. Nurcholis}

seperti Ali al-Hasan ibn Haistam (Alhazen) seorang ahli optika, astronomi, dan metematika, Jabir ibnu Hayyan (Gebert) seorang ahli kimia yang menggunakan pendekatan empiris sebagai penopang sebuah teori. Abu Bakar Al-Razi (Rhazes) seorang ahli kedokteran dan kimia. Ibnu Sina (Avicenna) ahli kedokteran, AlKhawarizmi ahli matematika dan aritmatika modern, Omar Khayyam, dan lain sebagainya. ${ }^{37}$ Pendek kata, Islam sebagai sebuah agama telah terbukti secara empiris telah mengambil peran dalam sejarah perkembangan sains melalui sarjana-sarjana muslim yang selain memiliki peran sebagai ahli ilmu agama (alim) dan fisolof, juga merupakan saintis terkemuka. ${ }^{38}$

Pengakuan tentang peran penting saintis muslim terhadap perkembangan sains di dunia modern, bukan hanya datang dari kelompok muslim sendiri, bahkan juga dari para sarjana Barat sendiri. Robert Stephen Briffault, mencatat informasi penting bahwa beberapa karya ulama-intelek muslim secara nyata telah diplagiat oleh para sarjana Barat. Roger Bacon, misalnya, seorang tokoh yang dicatat sebagai pencetus metode eksperimen -salah satu dasar metode keilmuan- telah melakukan tindakan plagiasi karya Ibnu Sina. Briffault, sebagaimana dicuplik Haidar Bagir, menilai bahwa Roger Bacon tidak layak mendapat kehormatan sebagai bapak metode eksperimen, sebaliknya ia hanyalah seorang pengantar metode pengetahuan dan sains yang berasal dari dunia Islam pada Eropa. ${ }^{39}$

Berdasarkan data-data di atas, teori tahapan teologis-fiktif yang diperankan oleh agama, metafisik-abstrak yang diperankan oleh filsafat, dan positif-riil yang diperankan oleh sains merupakan generalisir yang tentu tidak dapat diberlakukan dalam agama Islam. Teori Comte ini nampak sebagai bias paradigma sains yang menempatkan objek empirik sebagai satu-satunya sebuah realitas kebenaran dan sumber ilmu pengetahuan. Agama dengan sistem ketuhanannya (abstrak-supra

Qomar, Pendidikan Islam Multidispliner, Interdisipliner, Dan Transdisipliner, 80. Upaya integrasi ilmu agama dan ilmu umum menuntut adanya sikap saling terbuka dan berbagi diantara dua kelompok ulama dan intelek. Meski demikian dalam tataran praktik, menurut catatan Amin Abdullah, muncul sikap ketidakrelaan dari kelompok intelek muslim yang berpendidikan umum jika masalah-masalah sains dimasuki oleh kalangan agamawan. M. Amin Abdullah, Multidisiplin, Interdisiplin, Dan Transdisiplin: Metode Studi Agama Dan Studi Islam Di Era Kontemporer (Surakarta: Pusat Studi Budaya dan Perubahan Sosial Universitas Muhammadiyah Surakarta, 2020), 44.

${ }^{37}$ Abdalla, Sains Religius, Agama Saintifik: Dua Jalan Mencari Kebenaran, 82-84.

${ }^{38}$ Amril M, Epistemologi Integratif-Interkonektif Agama Dan Sains (Jakarta: Rajawali Pers, 2016), 91.

${ }^{39}$ Abdalla, Sains Religius, Agama Saintifik: Dua Jalan Mencari Kebenaran, 83. 
rasional), dan filsafat dengan rasionalnya (abstrak-rasional), dengan demikian, harus dianggap tidak ada sebab bertentangan dengan paradigma sains tersebut. Pembatasan objek kajian sains hanya pada wilayah empiris, sebagaimana diungkap Ahmad Tafsir, seharusnya tidak dimaknai sebagai bentuk penolakan sains terhadap keberadaan hal-hal yang ada di luarnya, akan tetapi justru harus dipandang sebagai bentuk kelemahan sains yang hanya mampu menangkap realitas yang terindera semata dan sekaligus dijangkau oleh akal pikiran. ${ }^{40}$

Haidar Bagir menjelaskan bahwa dalam kesejarahannya, metode ilmiah sains baru dikembangkan kurang dari lima ratus tahun (lima abad), tepatnya dimulai pasca terjadinya scientific revolution (kisaran tahun 1543 sampai dengan 1600 M.) dan berlaku hingga abad 21 saat ini. Artinya, dalam sejarah panjang ilmu pengetahuan, sebelum revolusi sains, umat manusia telah terbiasa menggunakan metode yang berbeda-beda untuk mendapatkan ilmu pengetahuan. Metode yang dominan digunakan oleh manusia dihampir sepanjang sejarah ilmu pengetahuan adalah hal yang disebut sebagai mistis. Berbeda dengan metode sains, dalam metode mistis manusia sebagai subjek pengetahuan tidak ditempatkan secara berjarak dengan alam sebagai objek pengetahuan, sebaliknya manusia menjalin hubungan interaksi partisipatif yang harmonis dengan hal-hal yang ada di luarnya. Pengetahuan dalam metode mistis lebih bersifat ontologis dan eksistensialis, yakni proses penggalian pengetahuan melalui perjumpaan kedua unsur yang saling terlibat secara aktif. ${ }^{41}$

Keberadaan metode sains harus dimaknai sebagai proses lanjutan dari metode penemuan ilmu pengetahuan yang telah ada sebelumnya dengan membatasi diri pada objek bersifat fisik dan menanggalkan metafisika yang telah lama dan sebagai permulaan wilayah kajian dalam dunia filsafat. ${ }^{42}$ Sains bagaimanapun juga tidak dapat sepenuhnya dilepaskan dari kajian filsafat, sebab ia muncul dan berkembang dari pemikiran para filosof tentang daya kekuatan untuk menemukan sebuah pengetahuan, apakah berupa indera semata seperti

\footnotetext{
40 Ahmad Tafsir, Filsafat Pendidikan Islami: Integrasi Jasmani, Rohani, Dan Kalbu Memanusiakan Manusia, 105.

${ }^{41}$ Haidar Bagir, Epistemologi Tasawuf, 37.

${ }^{42}$ Aksin Wijaya, Nalar Kritis Epistemologi Islam Membincang Dialog Kritis Para Kritikus Muslim: ALGhazali, Ibnu Rusyd, Thaha Husein, M. Abid Al-Jabiri, ed. Rufiah Nur Hasan (Yogyakarta: Kalimedia, 2017), 25 .
} 


\section{Moch. Nurcholis}

gagasan Heraclitus, apakah dari akal semata seperti pendapat Descartes, atau gabungan dari keduanya seperti pandangan Aristoteles, ataukah justru datang dari daya ide seperti gagasan Plato. ${ }^{43}$ Keterpaduan antara empirisme dan rasionalisme pada akhirnya telah berjasa besar dalam mengantarkan sains menuju perkembangannya yang begitu pesat. Metode sains, dengan demikian, tidak benarbenar melepaskan diri dari wilayah metafisika, akan tetapi lebih pada melakukan pergeseran objek kajian dari yang semula metafisika transendental menuju metafisika yang bercorak sekuler. ${ }^{44}$

Metafisika transendental menurut Ibnu Sina, sebagaimana dicuplik oleh Aksin Wijaya, merupakan filsafat teoritis yang paling tinggi. Sebab objek yang dibahas di dalamnya bukan lagi yang berkaitan dengan eksistensi dan batasan yang bersifat materi, seperti tuhan dan jiwa. Urutan fislsafat teoritis berikutnya adalah filsafat ilmu tengah yang membatasi objek kajiannya pada eksistensi yang memiliki materi dan tidak terikat dengan batasan-batasan tertentu. Sedangkan filsafat teoritis yang terakhir adalah filsafat ilmu rendah yang mengkaji persoalan eksistensi yang memiliki materi dan terkait dengan batasan-batasan tertentu. Objek kajian pada filsafat ilmu rendah ini adalah wilayah fisika (ilmu kealaman) yang selama ini menjadi bidang kajian sains. ${ }^{45}$ Dari pembagian yang telah dibuat oleh Ibnu Sina ini dapat diketahui bahwa posisi sains yang hanya mengkaji wilayah "materi terbatas" berada diurutan paling rendah jika dibanding dengan filsafat yang mengkaji persoalan "materi tidak terbatas", dan agama yang mengkaji wilayah yang tidak memiliki "materi dan tidak terbatas".

Berbeda dengan sains dalam pandangan yang berlaku di dunia Barat, menurut al-Farabi sains harus dimaknai secara luas dan tidak terbatas pada wilayah objek empirik semata. Sains dalam perspektif epistemologi, menurut alFarabi, sebagaimana diungkap oleh Amril, adalah badan keilmuan yang terorganisir yang memiliki tujuan, premis dasar, objek serta metode penyelidikan. ${ }^{46}$ Konsekwensi dari pandangan al-Farabi ini, sains tidak hanya

\footnotetext{
${ }^{43}$ Suparman Syukur, Epistemologi Islam Skolastik: Pengaruhnya Pada Pemikiran Islam Modern, 67.

${ }^{44}$ Haidar Bagir, Mengenal Filsafat Islam: Pengantar Filsafat Yang Ringkas, Menyeluruh, Praktis, Dan Transformatif.

${ }^{45}$ Aksin Wijaya, Satu Islam Ragam Epistemologi (Yogyakarta: Pustaka Pelajar, 2014), 61.

${ }^{46}$ Amril M, Epistemologi Integratif-Interkonektif Agama Dan Sains, 88.
} 
terbatas pada wilayah yang empirik semata, sebaliknya ia dapat menjangkau ilmu pengetahuan apapun secara luas sepanjang di dalamnya terkandung objek, metode penyelidikan (penelitian), paradigma, dan terbuka untuk terus dikembangkan. Disamping itu, pemaknaan epistemologi sains al-farabi membuka peluang terhadap masuknya seluruh keilmuan agama seperti tauhid, fikih, dan tasawwuf. Dengan kata lain, al-Farabi seakan ingin mengatakan bahwa Islam secara epistemologi memiliki cakupan yang lebih luas yang di dalamnya terkandung epistemologi sains Barat, sebab jika pada epistemologi sains Barat paling jauh hanya dapat menjangkau wilayah makrokosmos, maka dalam epistemologi keilmuan Islam dapat menjangkau mikro kosmos (manusia), makro kosmos (alam semesta), dan meta kosmos (tuhan) secara sekaligus.

Titik temu epistemologi keilmuan Islam dan sains juga dapat dimulai dari diskusi tentang law of nature (hukum alam) yang keberadaanya diyakini baik oleh saintis muslim maupun sanintis Barat. Hanya saja, jika saintis Barat berhenti pada keyakinan bahwa hukum alam sebagai pusat ilmu pengetahuan yang harus diungkap dengan nalar dan pengamatan (empirisme-rasionalisme), maka Islam berpandangan bahwa pusat ilmu pengetahuan justru berada pada diri Tuhan sebagai pengatur dan peletak hukum alam itu. Hukum alam -juga disebut dengan ayat kawniyah- dalam hal sebagai wadah ilmu pengetahuan, oleh Islam dianggap sama posisinya dengan al-Quran dan Hadis -sebagai ayat qawliyah- yang harus digali kandungannnya melalui proses interpretasi yang juga melibatkan pengamatan dan nalar.

Sumber ilmu pengetahuan dalam Islam adalah Tuhan itu sendiri yang dalam proses pengajarannya kepada manusia dilakukan melalui dua instrumen, yakni melalui penciptaan mikro dan makro kosmos berbentuk fenomena empirik dan melalui pengalaman batin (wahyu, intuisi) berbentuk fenomena al-Quran dan Hadis. Dalam memahami ilmu pengetahuan yang terkandung dalam keduanya, manusia melalui akal dan inderanya dituntut melakukan interpretasi secara aktif dan terus berkelanjutan untuk menuju satu titik sumber ilmu pengetahuan dan kebenaran hakiki, yakni Tuhan itu sendiri. Dalam kaitan inilah kiranya layak meminjam terminologi kaum sufi tentang tingkatan keyakinan kebanaran relitas. Petama, ilm al-yaqin (pengetahuan tentang kebenaran) yang dihasilkan melalui 


\section{Moch. Nurcholis}

burhani (metode menemukan kebenaran yang didasarkan pada keselarasan logika tanpa perlu melihat informasi teks maupun kenyataan empirik). Kedua, ain alyaqin (realitas kebenaran) yang didapatkan melalui bayani (metode memperolah kebenaran dengan berdasar pada penafsiran ayat qawliyah maupun ayat kawniyah). Ketiga, haqq al-yaqin (hakekat atau inti kebenaran) yang didapatkan melalui 'irfani (sebuah metode menemukan kebenaran melalui pengalaman spiritual secara langsung). ${ }^{47}$

Persinggungan epistemologi Islam dan sains dalam hal penemuan sebuah kebenaran (ilmu pengetahuan) bertemu pada titik ain al-yaqin melalui metode bayani. Bedannya, jika pada sains berhenti pada wilayah ain al-yaqin, Islam bergerak lebih jauh pada wilayah haqq al-yaqin. Hubungan Islam dengan sains dapat dinyatakan sebagai hubungan antara yang kulli, yakni Islam, dengan yang juz’ $i$, yakni sains.

\section{Kesimpulan}

Dari papaparn yang telah dijelaskan sebelumnya, dapat disimpulkan beberapa hal sebagaimana berikut:

Pertama, keterpisahan dunia Islam dengan sains lebih dikarenakan aspek historis, sosiologis, politis dan bukan karena faktor ajaran Islam. Islam sebagai sebuah ajaran yang komprehensif tidak menempatkan "ilmu Islam" dan "ilmu umum" dalam posisisi diametral-paradoksial. Buktinya, secara empiris Islam telah banyak menyumbangkan tokoh-tokoh terkemuka dalam bidang sains, yang selain ahli agama juga filosof dan saintis, seperti Ali ibn Haitsam, Jabir ibn Hayyan, alKhawarizmi, al-Kindi, al-Razi, Ibnu Sina dan lain sebagainya. Ketidak mampuan umat Islam dalam menjaga tradisi kajian sains, relasi umat Islam dengan dunia Barat dan kemunduran politik, pada sisi internal, dan traumatik ketertindasan kelompok saintis Barat terhadap tradisi agama (gereja) pada sisi eksternal, telah menjadikan keterlepasan sains dari diri Islam. Sains pada akhirnya dipandang bukan sebagai bagian dari agama baik oleh kalangan agamawan maupun kalangan saintis.

\footnotetext{
47 Fatima Rahma Rangkuti, "Implementasi Metode Tajribi, Burhani, Bayani, Dan Irfani Dalam Studi Filsafat Pendidikan Islam," Al-Muaddib : Jurnal Ilmu-Ilmu Sosial \& Keislaman (2019): 41.
} 
Kedua, upaya integrasi Islam dan sains dalam wilayah epistemologi, yakni persoalan bagaimana cara mendapatkan pengetahuan sepanjang mengenai objek, metode, dan kriteria ilmu pengetahuan. Sains membatasi objek penelitiannya pada ranah empirik yang diolah melalui metode ilmiah. Kebenaran dalam sains diukur menggunakan dua kriteri sekaligus yakni rasional dan empirik. Sedangkan Islam, memperluas objek kajiannya tidak terbatas pada ranah empirik berupa mikro kosmos dan makro kosmos yang dapat dikaji melalui nalar dan pengamatan tetapi juga dalam ranah meta kosmos melalui pengalaman batin. Kriterai kebenaran dalam Islam, selain rasional (burhani) dan empirik (bayani), juga diukur menggunakan wahyu dan intuisi (irfani). Dengan demikian, pola keselarasan epistemologi antara Islam dan sains menggunakan hubungan kulli-juz'i (universalpartikular). Dengan kata lain, sains merupakan salah satu bagian dari ajaran Islam dalam satu keutuhan dan kesatuan sistem yang disebut sebagai way of life (jalan hidup). 


\section{DAFTAR PUSTAKA}

Abdalla, Haidar Bagir dan Ulil Abshar. Sains Religius, Agama Saintifik: Dua Jalan Mencari Kebenaran. Bandung: PT. Mizan Pustaka, 2020.

Abu Yasid. Logika Ushul Fikih. Yogyakarta: IRCiSoD, 2019.

Ahmad Tafsir. Filsafat Pendidikan Islami: Integrasi Jasmani, Rohani, dan Kalbu Memanusiakan Manusia. Bandung: Remaja Rosdakarya, 2017.

Al-Faruqi, Ismai'il Raji. Islamisasi Pengetahuan, Terj. Anas Mahyuddin. Bandung: Pustaka, 1984.

Amril M. Epistemologi Integratif-Interkonektif Agama dan Sains. Jakarta: Rajawali Pers, 2016.

Habib, Zainal. Islamisasi Sains:Mengembangkan Integrasi, Mendialogkan Perspektif. Malang: UIN-MALANG PRESS, 2007.

Haidar Bagir. Epistemologi Tasawuf. Bandung: Mizan, 2018.

—. Mengenal Filsafat Islam: Pengantar Filsafat yang Ringkas, Menyeluruh, Praktis, dan Transformatif. Bandung: Mizan, 2020.

Idri. Epistemologi Ilmu Pengetahuan, Ilmu Hadis, dan Ilmu Hukum Islam. Jakarta: Prenadamedia Group, 2015.

J. Sudarminta. Epistemologi Dasar. Yogyakarta: Kanisius, 2002.

Juhaya S. Praja. Aliran-Aliran Filsafat dan Etika. Jakarta: Prenada Media, 2003.

Jujun S. Suriasumantri. Ilmu Pengetahuan. Jakarta: Yayasan Obor Indonesia, 2009.

Kenneth T. Gallagher. Epistemologi. Yogyakarta: Kanisius, 1994.

Khaldun, Abdurrahman Ibn. Muqaddimah. Damaskus: Dar Ya'rab, 2004.

Kuntowijoyo. Islam Sebagai Ilmu: Epistemologi, Metodologi, dan Etika. Yogyakarta: Tiara Wacana, 2007.

M. Amin Abdullah. Multidisiplin, Interdisiplin, Dan Transdisiplin: Metode Studi Agama Dan Studi Islam Di Era Kontemporer. Surakarta: Pusat Studi Budaya dan 
Perubahan Sosial Universitas Muhammadiyah Surakarta, 2020.

Mulyadhi Kartanegara. Integrasi Ilmu: Sebuah Rekonstruksi Holistik. Bandung: Arasy Mizan, 2005.

Qomar, Mujamil. Pendidikan Islam Multidispliner, Interdisipliner, dan Transdisipliner. Malang: Madani Media, 2020.

Rangkuti, Fatima Rahma. "Implementasi Metode Tajribi, Burhani, Bayani, Dan Irfani Dalam Studi Filsafat Pendidikan Islam.” Al-Muaddib : Jurnal Ilmu-Ilmu Sosial \& Keislaman (2019).

Saepuddin, AM. Desekularisasi Pemikiran, Landasan Islamisasi Sains. Bandung: Mizan, 1996.

Salam, Abdus. Sains Dan Dunia Islam Menghidupkan Kembali Sains Di Negaranegara Arab Dan Islam, Terj. Achmad Baiquni. Bandung: Pustaka, 1982.

Sayed Muhammad Naquib al-Attas. Islam dan Filsafat Sains. Bandung: Mizan, 1989.

Suparman Syukur. Epistemologi Islam Skolastik: Pengaruhnya Pada Pemikiran Islam Modern. Yogyakarta: Pustaka Pelajar, 2007.

Wijaya, Aksin. Nalar Kritis Epistemologi Islam Membincang Dialog Kritis para Kritikus Muslim: AL-Ghazali, Ibnu Rusyd, Thaha Husein, M. Abid Al-Jabiri. Diedit oleh Rufiah Nur Hasan. Yogyakarta: Kalimedia, 2017.

—. Satu Islam Ragam Epistemologi. Yogyakarta: Pustaka Pelajar, 2014. 